\title{
Pengaruh Hubungan Gerakan Penerapan Pengelolaan Tanaman Terpadu (GP-PTT) dengan Peningkatan Produksi Tanaman Kedelai
}

\section{The Effect of Movement Related Application Management Integrated Plant (GP-PTT) with Improvement Soybean Production Plant}

\section{Zulkarnain}

Sekolah Tinggi Ilmu Pertanian (STIPER) Dharma Wacana Metro

J1. Kenanga No. 3 Mulyojati 16C Kota Metro, Lampung

e-mail : zulfadhilalzabir@gmail.com

\begin{abstract}
Food crops sector as producers of staple food for the people of Indonesia, so that this role can not be substituted fully by other sectors except food imports. Soybean crop is one of the staple food for the people of Indonesia that demand is increasing, therefore the government held a movement program Implementation of Integrated Crop Management (GP-PTT) to increase soybean production. The purpose of this study was to analyze the effect of the relationship Movement Implementation of Integrated Crop Management (GP-PTT) in the increased production of soybeans in Rejo village Binangun Raman District of North East Lampung district. The method used is a qualitative and quantitative methods. The sample was 27 farmers were taken by systematic random sampling technic. Data analysis method used is the analysis method validity, reliability, and Spearman rank test. This research was conducted in the village of Rejo Binangun Raman District of North East Lampung district in April 2016. The results showed that the the factors related to business assistance in relation Movement Application Processing Integrated Plant (GP-PTT) with an increase in the production of soybean on variable business assistance, PPT technology component, group participation. The third variable business assistance, the variable component PPT technology, variable group participation are of marked meaning if the higher aid farming, technology components, and group participation, the interest of farmers for the higher soybean.
\end{abstract}

Keyword: Integrated Crop Management, Production, Soybean Plant

Diterima : 13 Juli 2016, disetujui 12 September 2016

\section{PENDAHULUAN}

Subsektor tanaman pangan memegang peranan penting dalam perekonomia rakyat yang mayoritas bermata pencaharian sebagai petani. Tanaman pangan merupakan tanaman yang dibudidayakan untuk memenuhi kebutuhan manusia seperti karbohidrat, lemak, dan protein yang berasal dari bahan pangan nabati. Jenis tanaman pangan yang sering dibudidayakan seperti padi, jagung, serealia, ubi-ubian, dan kacangkacangan (kedelai, kacang hijau, kacang tanah, kacang tunggak dan kacang koro). Diantara jenis legum, kedelai merupakan sumber protein paling baik karena mempunyai susunan asam amino esensial paling lengkap. Disamping itu kedelai juga dapat digunakan sebagai sumber lemak, vitamin, mineral, dan serat (Sundarsih dan Kurniati, 2009).

Kebutuhan kedelai nasional mencapai 2,6 juta ton per tahun, sedangkan produksi kedelai Indonesia hanya mampu mencapai 800.000 ton per tahun. Dalam upaya pemenuhan kebutuhan kedelai tersebut, 

Zulkarnain : Pengaruh Hubungan Gerakan Penerapan Pengelolaan Tanaman Terpadu(Gp-Ptt) dengan Peningkatan...

Indonesia sebagai negara produsen kedelai hanya didukung dengan luas panen 615.685 ha (Badan Pusat Statistik, 2014).

Tabel 1. Neraca Produksi dan Kebutuhan Kedelai di Indonesia, Tahun (2013-2014).

\begin{tabular}{cccc}
\hline Uraian & 2013 & 2014 & Selisih \\
\hline Produksi Kedelai (Ton Biji Kering) & 779.992 & 954.997 & 175.005 \\
Kebutuhan (Ton Biji Kering) & 2.115 .700 & 2.235 .614 & 119.914 \\
Surplus/Defisit (Ton Biji Kering) & $(1.335 .708)$ & $(1.280 .617)$ & $(21.430)$ \\
Indeks Swasembada (\% & 36,86 & 41,21 & 4,38 \\
\hline
\end{tabular}

Sumber : Direktorat Jendral Tanaman Pangan, Kementrian Pertanian 2015

Tabel 1. menunjukan bahwa capaian produksi kedelai nasional tahun 2014 mengalami peningkatan dari tahun 2013 meskipun belum mencapai target yang di butuhkan. Dari data Direktorat Jendral Tanaman Pangan, Kementrian Pertanian 2014, produksi kedelai selama periode tahun 2013-2014 menunjukan trend pertumbuhan yang positif, meningkat dari 779 ribu ton pipilan kering pada tahun 2013 menjadi 954 ribu ton pipilan kering tahun 2014. Tingginya capaian produksi kedelai tahun 2014 disebabkan antara lain : Peningkatan luas panen terjadi karena adanya realisasi program perluasan areal tanam (PAT) kedelai, adanya pemanfaatan lahan hutan untuk pertanaman kedelai, adanya jaminan harga dan dukungan pemerintah daerah. Khusus di lokasi Sekolah Lapang-Pengelolaan Tanaman Terpadu (SL-PTT) capaian produktivitasnya lebih tinggi bila dibandingkan dengan produktivitas nasional. Akan tetapi ada di sebagian daerah atau lokasi yang mengikuti Sekolah Lapang-Pengelolaan Tanaman Terpadu (SL-PTT) capaian produktivitasnya rendah hal tersebut disebabkan antara lain : penggunaan komponen teknologi anjuran belum sepenuhnya dipahami dan diterapkan oleh petani, ketersediaan dan penggunaan benih unggul bermutu masih terbatas, kurangnya pengawalan dan pendampingan oleh penyuluh dan peneliti, serta penerapan paket teknologi sesuai anjuran berdasarkan hasil analisis kondisi dan potensi lapangan belum sepenuhnya diterapkan.

Provinsi Lampung merupakan salah satu provinsi yang ada di Indonesia sebagai penghasil komoditi kedelai. Perkembangan produksi tanaman kedelai di Provinsi Lampung cenderung berfluktuasi selama periode 2010-2014. Perubahan yang paling mencolok terjadi di tahun 2011 di mana pada saat itu produksi kedelai melonjak hingga mencapai 10,98 ribu ton biji kering (BK). Produksi ini meningkat 49,95 persen dibandingkan dengan tahun sebelumnya. Akan tetapi, pada tahun 2012, produksi kedelai justru turun 27,23 persen hingga menjadi 7,99 ribu ton BK. Kondisi ini disebabkan berkurangnya luas panen 2,52 ribu hektar, namun produktivitasnya meningkat 0,68 kuintal. Tahun 2013 turun hingga mencapai 6,16 ribu ton BK atau turun 22,98 persen dibandingkan dengan tahun sebelumnya. Produksi tahun 2013 dari luas panen sebesar 4,99 ribu hektar dan produktivitas sekitar 12,35 kuintal per hektar. Namun pada tahun 2014 produksinya naik pesat menjadi 13,78 ribu ton biji kering (BK) atau sekitar 123,80 \% (BPS Provinsi Lampung, 2015).

Dalam rangka meningkatkan ketahanan pangan, khususnya ketersediaan bahan pangan kedelai, di perlukan upaya yang sungguh-sungguh untuk meningkatkan produksinya dan tentunya harus diprogramkan secara teliti, terencana, berjangka panjang dan tepat sasaran. Tujuan utamanya adalah untuk meningkatkan produksi dalam negeri secara bertahap sehingga secara bertahap pula kebutuhan kedelai melalui impor bisa berkurang atau hanya dilakukan apabila kebutuhan dalam negeri benar-benar tidak dapat terpenuhi (Adi Sarwanto, 2008).

Kecamatan Raman Utara merupakan salah satu daerah yang ada di Kabupaten Lampung Timur yang ikut serta atau berupaya meningkatkan produksi kedelai. Perkembangan produksi kedelai selama 4 tahun terakhir (2011-2014) di Kabupaten Raman Utara menunjukan trend pertumbuhan produksi yang positif pada tahun 2011-2013. Menyadari bahwa kedelai merupakan bahan pangan yang penting bagi masyarakat, maka 
pemerintah mengadakan program Gerakan Penerapan Pengelolaan Tanaman Terpadu (GP-PTT) untuk meningkatkan produksi tanaman kedelai. Untuk merealisasikan program tesebut, maka petani kedelai di Desa Rejo Binangun Kecamatan Raman Utara dengan Dinas Pertanian melakukan kejasama untuk merumuskan beberapa petunjuk program bagi pelaksanaan pengembangan tanaman kedelai guna meningkatan produksi kedelai.

Sesuai dengan permasalahan yang telah dirumuskan di atas, maka tujuan yang hendak dicapai dalam penelitian ini adalah untuk mengetahui pengaruh hubungan Gerakan Penerapan Pengelolaan Tanaman Terpadu (GP-PTT) dengan peningkatan produksi tanaman kedelai.

\section{METODE}

Lokasi penelitian dipilih secara sengaja (purposive) yaitu di Desa Rejo Binangun Kecamatan Raman Utara Kabupaten Lampung Timur dengan pertimbangan bahwa daerah tersebut merupakan sentra produksi kedelai dengan areal tanam kedelai seluas 60 hektar dan mendapatkan program GP-PTT dari pemerintah (BP3K Kecamatan Raman Utara). Pelaksanaan penelitian pada bulan Februari 2016. Populasi dalam penelitian ini adalah petani kedelai seluas 60 ha yang beranggotakan 135 orang, pengambilan ukuran sampel untuk petani kedelai didasarkan pada teori yang dikemukakan oleh Yamane (Sugiarto et al, 2003 dalam Zulkarnain et al, 2010). Cara pengambilan sampel dilakukan dengan menggunakan Teknic Systematic random sampling.

Metode yang digunakan dalam penelitian ini adalah metode survei dengan menggunakan data primer dan sekunder. Data primer diperoleh melalui teknik wawancara (pengisian kuesioner) langsung dengan petani kedelai di Desa Rejo Binangun Kecamatan Raman Utara Kabupaten Lampung Timur. Data sekunder bersumber dari beberapa lembaga/instansi terkait dalam penelitian ini seperti Dinas Pertanian Provinsi maupun Kabupaten, Biro Pusat Statistik (BPS) serta pihak terkait lainnya yang berhubungan dengan informasi pendataan; luas areal, produksi, dan produktivitas dan berbagai data pendukung lainnya.

Menurut Husein Umar (2003) mengemukakan teknik kuesioner merupakan suatu pengumpulan data yang diberikan respon atas daftar pertanyaan tersebut. Tujuan mengadakan kuesioner ini adalah untuk memperoleh informasi yang relevan, dimana isi dari kuesioner tersebut mengenai data responden, bantuan sarana produksi, komponen teknologi Pengelolaan Tanaman Terpadu (PTT), adopsi teknologi Pengelolaan Tanaman Terpadu (PTT), partisipasi kelompok. Dalam pengambilan sampel penelitian ini, kuesioner dibagikan secara langsung kepada petani. Kuesioner yang disebar langsung kepada responden sejumlah 27 kuesioner.

Teknik Analisis Data. Analisis kualitatif merupakan penganalisisan data yang tidak dapat dinominalkan dengan menggunakan angka-angka, melainkan disajikan berupa keterangan, penjelasan dan pembahasan teori. Dari analisis tersebut kemudian dibuat penyajian atau pengujian, untuk mengetahui hubungan Gerakan Penerapan Pengelolaan Tanaman Terpadu (GP-PTT) dengan peningkatan produksi tanaman kedelai dengan menggunakan uji rank spearman. Uji rank spearman digunakan untuk mengetahui mengetahui tingkat keeratan hubungan yang dimiliki antar variabel dalam penelitian. Dasar pengambilan keputusan dalam uji rank spearman yaitu jika nilai sig < 0,05 maka, dapat disimpulkan bahwa terdapat korelasi yang signifikan antara variabel yang dihubungkan. Sebaliknya, jika nilai sig > 0,05 maka dapat disimpulkan bahwa tidak terdapat korelasi yang signifikan antara variabel yang dihubungkan (Sarwono, 2015).

Pengumpulan data digunakan instrumen berupa kuesioner. Jenis kuesioner yang digunakan adalah kuesioner tertutup yaitu merupakan seperangkat daftar pertanyaan dengan kemungkinan jawaban yang telah disediakan, responden hanya memilih salah satu dari beberapa alternatif jawaban yang disediakan dalam bentuk skala likert. Pengukuran yang digunakan dalam penelitian ini dengan pengujian terhadap kualitas 
Zulkarnain : Pengaruh Hubungan Gerakan Penerapan Pengelolaan Tanaman Terpadu(Gp-Ptt) dengan Peningkatan...

data. Menurut Hair et. al. (1998) dalam Ernawati S., 2011 kualitas data dihasilkan dari penggunaan instrumen penelitian dapat dievaluasi melalui uji validitas dan uji reliabilitas. Uji ini dimaksudkan untuk mengetahui konsisten dan akurasi data yang dikumpulkan dari penggunaan instrumen.

Uji reliabilitas dimaksudkan untuk mengetahui konsisten instrumen yang digunakan. Uji reliabilitas dilakukan dengan menghitung cronbach alpha lebih dari 0,60 (Nunnally (1969) dalam Ernawati S., 2011). Menurut Arikunto (2006), validitas merupakan suatu ukuran yang menunjukkan tingkat-tingkat kevalidan dan keahlian suatu instrumen. Suatu instrumen dikatakan valid apabila memiliki validitas tinggi, sebaliknya instrumen dikatakan kurang valid apabila memiliki validitas rendah. Validitas dianggap memuaskan apabila nilai > 0,3 (Trihendradi, 2012). Semakin tinggi nilai koefisien korelasi maka item pertanyaan semakin valid. (Hamidi, 2007 dalam Semuel dan Saputra, 2013) Rumus yang digunakan untuk menghitung tingkat validitas adalah Pearson Correlation Product Moment sebagai berikut :

$$
r_{x y}=\frac{N \sum X Y-\left(\sum X\right)\left(\sum Y\right)}{\sqrt{\left\{N \sum X^{2}-\left(\sum X\right)^{2}\right\}\left(N \sum Y^{2}-\left(\sum Y\right)^{2}\right\}}}
$$

Keterangan

$\begin{array}{ll}\mathrm{r}_{\mathrm{xy}} & =\text { Koefisien korelasi antara variabel } \mathrm{X} \text { dan variable } \mathrm{Y} \\ \mathrm{N} & =\text { Jumlah sampel } \\ \sum \mathrm{X}^{2} & =\text { Kuadrat faktor variabel } \mathrm{X} \\ \sum \mathrm{Y}^{2} & =\text { Kuadrat faktor variabel } \mathrm{Y} \\ \sum \mathrm{XY} & =\text { Jumlah perkalian faktor korelasi variabel } \mathrm{X} \text { dan } \mathrm{Y}\end{array}$

\section{HASIL DAN PEMBAHASAN}

\section{Pengujian Instrumen}

Uji validitas. Uji validitas dilakukan untuk mengetahui sejauh mana kuesioner mengukur apa yang diinginkan. Untuk mengukur validitas digunakan korelasi product moment pearson. Jika korelasi product moment pearson antara masing-masing pertanyaan dengan skor total menghasilkan nilai korelasi $>0.3$, maka item pertanyaan dinyatakan valid. Berikut adalah hasil pengujian validitas masing-masing item pertanyaan pada variabel penelitian.

Tabel 2. Hasil Uji Validitas

\begin{tabular}{|c|c|c|c|c|c|c|}
\hline Variabel & $\begin{array}{c}\text { Bantuan } \\
\text { Usaha }\end{array}$ & $\begin{array}{c}\text { Komponen } \\
\text { Teknologi PTT }\end{array}$ & $\begin{array}{c}\text { Adopsi } \\
\text { Teknoogi } \\
\text { PTT }\end{array}$ & Penyuluh & $\begin{array}{l}\text { Partisipasi } \\
\text { Kelompok }\end{array}$ & Keterangan \\
\hline Instrumen 1 & 0,328 & & & & & Valid \\
\hline Instrumen 2 & 0,531 & & & & & Valid \\
\hline Instrumen 3 & 0,624 & & & & & Valid \\
\hline Instrumen 4 & 0,503 & & & & & Valid \\
\hline Instrumen 5 & 0,868 & & & & & Valid \\
\hline Instrumen 1 & & 0,692 & & & & Valid \\
\hline Instrumen 2 & & 0,485 & & & & Valid \\
\hline Instrumen 3 & & 0,843 & & & & Valid \\
\hline Instrumen 4 & & 0,791 & & & & Valid \\
\hline Instrumen 5 & & 0,863 & & & & Valid \\
\hline Instrumen 1 & & & 0,930 & & & Valid \\
\hline
\end{tabular}




\begin{tabular}{|c|c|c|c|c|c|c|}
\hline Variabel & $\begin{array}{c}\text { Bantuan } \\
\text { Usaha }\end{array}$ & $\begin{array}{c}\text { Komponen } \\
\text { Teknologi PTT }\end{array}$ & $\begin{array}{c}\text { Adopsi } \\
\text { Teknoogi } \\
\text { PTT }\end{array}$ & Penyuluh & $\begin{array}{l}\text { Partisipasi } \\
\text { Kelompok }\end{array}$ & Keterangan \\
\hline Instrumen 2 & & & 0,403 & & & Valid \\
\hline Instrumen 3 & & & 0,617 & & & Valid \\
\hline Instrumen 4 & & & 0,372 & & & Valid \\
\hline Instrumen 5 & & & 0,483 & & & Valid \\
\hline Instrumen 1 & & & & 0,452 & & Valid \\
\hline Instrumen 2 & & & & 0,355 & & Valid \\
\hline Instrumen 3 & & & & 0,468 & & Valid \\
\hline Instrumen 4 & & & & 0,696 & & Valid \\
\hline Instrumen 5 & & & & 0,634 & & Valid \\
\hline Instrumen 1 & & & & & 0,713 & Valid \\
\hline Instrumen 2 & & & & & 0,376 & Valid \\
\hline Instrumen 3 & & & & & 0,307 & Valid \\
\hline Instrumen 4 & & & & & 0,576 & Valid \\
\hline Instrumen 5 & & & & & 0,695 & Valid \\
\hline
\end{tabular}

Sumber : data olahan (2015)

Tabel 2. menunjukkan bahwa nilai pearson correlation $\geq 0,30$ (Trihendradi, 2012) berarti variabel bantuan usaha, teknologi pengolahan tanaman terpadu, adopsi teknologi pengolahan tanaman terpadu, penyuluh, dan partisipasi kelompok adalah valid.

Uji reliabilitas. Suatu kuesioner dikatakan reliabel jika jawaban seseorang terhadap pernyataan adalah konsisten atau stabil dari waktu ke waktu. Uji reliabilitas dimaksudkan untuk mengetahui konsisten instrumen yang digunakan. Uji reliabilitas dilakukan dengan menghitung cronbach alpha lebih dari 0,60 (Nunnally (1969) dalam Ernawati S., 2011). Hasil pengujian reliabilitas dengan menggunakan SPSS 16.0 For Windows dapat dilihat pada Tabel 2.

Tabel 3. Hasil Uji Reliabilitas

\begin{tabular}{lcc}
\hline \multicolumn{1}{c}{ Variabel } & Alpha Cronbach & Keterangan \\
\hline Bantuan usaha & 0,766 & Reliabel \\
Komponen Teknologi PTT & 0,759 & Reliabel \\
Adopsi teknologi PPT & 0,642 & Reliabel \\
Penyuluh & 0,613 & Reliabel \\
Partisipasi kelompok & 0,805 & Reliabel \\
\hline
\end{tabular}

Sumber : data olahan (2015)

Tabel 3. menunjukkan bahwa nilai Alpha Cronbach $\geq 0,60$ (Numally 1969 dalam Ernawati S., 2011) berarti bahwa variabel bantuan usaha, teknologi pengolahan tanaman terpadu, adopsi teknologi pengolahan tanaman terpadu, penyuluh, dan partisipasi kelompok adalah reliabel.

\section{Pengaruh Hubungan Gerakan Penerapan Pengelolaan Tanaman Terpadu (GP-PTT) pada peningkatan produksi tanaman kedelai}

Analisis uji rank spearman. Hubungan antara variabel X (bantuan usaha, komponen teknologi, adopsi teknologi PPT, penyuluh dan partisipasi kelompok) dengan variabel Y (peningkatan produksi kedelai) dianalisis dengan menggunakan statistika non parametrik uji korelasi Rank Spearman. Dasar pengambilan keputusan dalam uji rank spearman yaitu jika nilai sig < 0,05 maka, dapat disimpulkan bahwa terdapat korelasi yang signifikan antara variabel yang dihubungkan (Sarwono, 2015). Hasil pengujian secara statistik 
Zulkarnain : Pengaruh Hubungan Gerakan Penerapan Pengelolaan Tanaman Terpadu(Gp-Ptt) dengan Peningkatan...

terhadap pengaruh hubungan Gerakan Penerapan Pengelolaan Tanaman Terpadu (GP-PTT) dengan peningkatan produksi tanaman kedelai dapat dilihat pada Tabel 3.

Tabel 4. Hasil analisis hubungan antara variabel bebas (X) dengan variabel terikat (Y)

\begin{tabular}{lccc}
\hline \multicolumn{1}{c}{ Variabel X } & Variabel Y & $\mathrm{r}_{\mathrm{s}}$ & $\mathrm{t}_{\text {test }}$ \\
\hline $\mathrm{X} 1$ : bantuan usaha & & $-0,120$ & $1,249^{*}$ \\
$\mathrm{X} 2$ : komponan teknologi & GP-PTT dengan & $-0,208$ & $2,230^{* *}$ \\
$\mathrm{X} 3$ : adopsi teknologi PPT & peningkatan produksi & 0,452 & 0,887 \\
$\mathrm{X} 4$ : penyuluh & tanaman kedelai & 0,189 & 0,076 \\
$\mathrm{X} 5$ : partisipasi kelompok & & $-0,156$ & $2,164^{*}$ \\
\hline
\end{tabular}

Keterangan:

*Berhubungan nyata pada taraf kepercayaan $95 \%\left(\mathrm{t}_{\text {tabel }}=1,679\right)$

** Berhubungan nyata pada taraf kepercayaan $99 \%\left(\mathrm{t}_{\text {tabel }}=2,473\right)$

Tabel 4 menunjukkan bahwa variabel-variabel yang berhubungan nyata pada penelitian pengaruh hubungan Gerakan Penerapan Pengelolaan Tanaman Terpadu (GP-PTT) pada peningkatan produksi tanaman kedelai adalah bantuan usaha, komponen teknologi Pengelolaan Tanaman Terpadu (PPT) dan partisipasi kelompok. Sedangkan variabel yang tidak berhubungan nyata adalah adopsi teknologi Pengelolaan Tanaman Terpadu (PPT) dan penyuluh. Berikut ini uraian masing-masing variabel. Untuk memperjelas hubungan antara variabel $\mathrm{Y}$ dan variabel $\mathrm{X}$ maka dapat dijelaskan sebagai berikut :

Hubungan antara bantuan usaha dengan peningkatan produksi tanaman kedelai. Hasil pengujian hipotesis hubungan antara bantuan usaha dengan peningkatan produksi kedelai dalam hubungan Gerakan Penerapan Pengelolaan Tanaman Terpadu (GP-PTT) dengan uji korelasi rank spearman diperoleh nilai $t_{\text {test }}$ sebesar 1,249. Nilai $t_{\text {test }}$ sebesar 1,249 lebih besar dibandingkan dengan nilai $t_{\text {tabel }}$ pada tingkat $95 \%$ $(\mathrm{n}-2)$ yaitu sebesar 1,679 artinya terima $\mathrm{H} 1$ pada $\alpha 0,05$, yaitu terdapat hubungna yang nyata antara bantuan usaha dengan hubungan Gerakan Penerapan Pengelolaan Tanaman Terpadu (GP-PTT) pada peningkatan produksi tanaman kedelai.

Keadaan ini menunjukkan bahwa bantuan usaha memiliki hubungan erat dengan hubungan Gerakan Penerapan Pengelolaan Tanaman Terpadu (GP-PTT) pada peningkatan produksi tanaman kedelai, artinya bantuan usaha menentukan dalam mengambil keputusan untuk meningkatkan produksi. Semakin besar bantuan usaha yang diterima oleh petani maka semakin besar kemampuan petani untuk melakukan usahatani kedelai sehingga akan meningkatkan pendapatan petan. Kemudian kemudahan untuk berusahatani semakin mudah karena untuk budidaya tanaman kedelai sudah cukup diberikan dari program Gerakan Penerapan Pengelolaan Tanaman Terpadu (GP-PTT).

Hubungan antara komponen teknologi dengan peningkatan produksi tanaman kedelai. Hasil pengujian hipotesis hubungan antara komponen teknologi dengan peningkatan produksi kedelai dalam hubungan Gerakan Penerapan Pengelolaan Tanaman Terpadu (GP-PTT) dengan uji korelasi rank spearman diperoleh nilai $t_{\text {test }}$ sebesar 2,230. Nilai $t_{\text {test }}$ sebesar 2,230lebih besar dibandingkan dengan nilai $t$ tabel pada tingkat $95 \%(\mathrm{n}-2)$ yaitu sebesar 1,679 artinya terima $\mathrm{H} 1$ pada $\alpha 0,05$, yaitu terdapat hubungan yang nyata antara komponen teknologi dengan hubungan Gerakan Penerapan Pengelolaan Tanaman Terpadu (GP-PTT) dalam peningkatan produksi tanaman kedelai.

Keadaan ini menunjukkan bahwa komponen teknologi dapat memberikan varietas yang unggul untuk petani yang tahan akan hama penyakit dan memberikan benih yang berlabel sehingga hasil produksi tanaman kedelai yang dibudidayakan memiliki potensi hasil yang baik. Selain itu, semakin banyak jenis teknologi pengelolaan tanaman terpadu yang di terima oleh petani maka semakin mudah petani untuk meningkatkan produksi kedelai. 
Hubungan antara adopsi teknologi Pengelolaan Tanaman Terpadu (PPT) dengan peningkatan produksi tanaman kedelai. Hasil pengujian hipotesis hubungan antara adopsi teknologi Pengelolaan Tanaman Terpadu (PPT) dengan peningkatan produksi kedelai dalam hubungan Gerakan Penerapan Pengelolaan Tanaman Terpadu (GP-PTT) dengan uji korelasi rank spearman diperoleh nilai $\mathrm{t}_{\text {test }}$ sebesar 0,887. Nilai $\mathrm{t}_{\text {test }}$ sebesar 0,887 lebih kecil dibandingkan dengan nilai $\mathrm{t}$ tabel pada tingkat $95 \%(\mathrm{n}-2)$ yaitu sebesar 1,679 artinya tolak $\mathrm{H} 1$ pada $\alpha 0,05$, yaitu tidak terdapat hubungan yang nyata antara adopsi teknologi Pengelolaan Tanaman Terpadu (PPT) dengan Gerakan Penerapan Pengelolaan Tanaman Terpadu (GP-PTT) dalam peningkatan produksi tanaman kedelai.

Berdasarkan uraian diatas dapat disimpulkan bahwa adopsi teknologi Pengelolaan Tanaman Terpadu (PPT) yang diberikan oleh Gerakan Penerapan Pengelolaan Tanaman Terpadu (GP-PTT) kurang berjalan maksimal. Dari hasil pengamatan dilapangan dapat dilihat bahwa adopsi teknologi PTT yakni bantuan program Gerakan Penerapan Pengelolaan Tanaman Terpadu (GP-PTT) benih bermutu tidak teralokasikan dengan baik pada petani di Desa Rejo Binangun, serta perubahan teknologi yang baru menjadikan petani enggan mengaplikasikannya pada lahan garapan. Petani masih menggunakan metode manual untuk membudidayakan tanaman kedelai.

Hubungan antara penyuluh dengan peningkatan produksi tanaman kedelai. Hasil pengujian hipotesis hubungan antara penyuluh dengan peningkatan produksi kedelai dalam hubungan Gerakan Penerapan Pengelolaan Tanaman Terpadu (GP-PTT) dengan uji korelasi rank spearman diperoleh nilai $t_{\text {test }}$ sebesar 0,076. Nilai $\mathrm{t}_{\text {test }}$ sebesar 0,076 lebih kecil dibandingkan dengan nilai $\mathrm{t}_{\text {tabel }}$ pada tingkat $95 \%(\mathrm{n}-2)$ yaitu sebesar 1,679 artinya tolak H1 pada $\alpha 0,05$, yaitu tidak terdapat hubungan yang nyata antara penyuluh dengan hubungan Gerakan Penerapan Pengelolaan Tanaman Terpadu (GP-PTT) dalam peningkatan produksi tanaman kedelai.

Berdasarkan uraian diatas dapat disimpulkan bahwa penyuluhan yang diberikan oleh Gerakan Penerapan Pengelolaan Tanaman Terpadu (GP-PTT) kurang berjalan maksimal. Padahal, penyuluh pertanian merupakan salah satu pemberdayaan petani untuk meningkatkan produktivitas, pendapatan dan kesejahteraannya. Untuk itu kegiatan penyuluhan pertanian harus dapat mengakomodasikan aspirasi dan peran aktif petani dan pelaku usaha pertanian lainnya melalui pendekatan partisipatif. Pengembangan pembangunan pertanian di masa mendatang perlu memberikan perhatian yang khusus terhadap penyuluhan pertanian, karena penyuluhan pertanian merupakan salah satu kegiatan yang strategis dalam upaya pencapaian tujuan pembangunan pertanian. Melalui kegiatan penyuluhan, petani ditingkatkan kemampuannya agar dapat mengelola usaha taninya dengan produktif, efisien dan menguntungkan, sehingga petani dan keluarganya dapat meningkatkan kesejahteraanya. Meningkatnya kesejahteraan petani dan keluarganya adalah tujuan utama dari pembangunan pertanian. Dalam hal ini, penyuluh kurang memberikan perhatian yang lebih pada petani kedelai yang sebenarnya merupakan tugas wajib untuk mewujudkan swasembada pangan yang salah satunya adalah tanaman kedelai.

Hubungan antara partisipasi kelompok dengan peningkatan produksi tanaman kedelai. Hasil pengujian hipotesis hubungan antara partisipasi kelompok dengan peningkatan produksi kedelai dalam hubungan Gerakan Penerapan Pengelolaan Tanaman Terpadu (GP-PTT) dengan uji korelasi rank spearman diperoleh nilai $t_{\text {test }}$ sebesar 2,164. Nilai $t_{\text {test }}$ sebesar 2,164 lebih kecil dibandingkan dengan nilai $t$ tabel pada tingkat $95 \%(\mathrm{n}-2)$ yaitu sebesar 2,164 artinya tolak H1 pada $\alpha 0,05$, yaitu terdapat hubungan yang nyata antara partisipasi kelompok dengan hubungan Gerakan Penerapan Pengelolaan Tanaman Terpadu (GP-PTT) dalam peningkatan produksi tanaman kedelai.

Hasil pengamatan menunjukkan bahwa secara umum petani memilliki hak serta kewajiban yang sama dalam melaksanakan Gerakan Penerapan Pengelolaan Tanaman Terpadu (GP-PTT) serta aktif dalam memberikan ide, pendapat dalam pertemuan kelompok guna meningkatkan produksi tanaman kedelai agar 
meningkat. Sehingga dapat disimpulkan bahwa semakin tinggi partisipasi kelompok maka semakin tinggi peningkatan produksi tanaman kedelai dalam penerapan Gerakan Penerapan Pengelolaan Tanaman Terpadu (GP-PTT). Hal ini sudah tentu dapat mendukung petani untuk meningkatkan produksi tanaman kedelai dengan hubungan gerakan Gerakan Penerapan Pengelolaan Tanaman Terpadu (GP-PTT).

\section{KESIMPULAN DAN SARAN}

Hubungan Gerakan Penerapan Pengolahan Tanaman Terpadu (GP-PTT) pada peningkatan produksi tanaman kedelai berpengaruh nyata pada bantuan usaha, komponen teknologi pengelolaan tanaman terpadu (PTT) dan partisipasi kelompok. Petani kedelai sangat membutuhkan biaya untuk keberlangsungan usahataninya dimana bantuan usaha sangat menentukan dalam mengambil keputusan berusahatani, selain itu kemudahan untuk berusahatani semakin mudah karena untuk budidaya tanaman kedelai sudah cukup diberikan dari program Gerakan Penerapan Pengelolaan Tanaman Terpadu (GP-PTT). Kemudian komponen teknologi yang didapatkan oleh petani kedelai berupa varietas yang unggul yang tahan akan hama penyakit dan berlabel sehingga hasil produksi tanaman kedelai yang dibudidayakkan memiliki potensi hasil yang baik. Selain itu, petani memilliki hak serta kewajiban yang sama dalam melaksanakan Gerakan Penerapan Pengelolaan Tanaman Terpadu (GP-PTT) serta aktif dalam memberikan ide, pendapat dalam pertemuan kelompok guna meningkatkan produksi tanaman kedelai agar meningkat. Sehingga dengan adanya bantuan usahatani, komponen teknologi, dan partisipasi kelompok maka akan meningkatkan minat petani untuk berusahatani kedelai.

\section{DAFTAR PUSTAKA}

Arikunto. 2006. Prosedur Penelitian Suatu Pendekatan Praktik. Jakarta : Rineka Cipta.

Badan Pusat Statistik Provinsi Lampung. 2015. BPS Provinsi Lampung. Bandar Lampung. http://lampung.bps.go.id/website/pdf_publikasi/Produksi-Tanaman-Palawija--Provinsi-Lampung2010--2014.pdf.(diakses tanggal 10 november 2015)

Ernawati, S. 2011. Pengaruh Pemahaman Akuntansi Pajak Terhadap Kepatuhan Wajib Pajak Badan Usaha Di bidang Perdagangan Di Kantor Pelayanan Pajak Pratama Banjarmasin. Jurnal Spred 1 (1) : 74 - 86.

Ghozali, Imam. 2006. Analisis Multivariate dengan Program SPSS. Edisi keempat. Semarang : Badan Penerbit Universitas Diponegoro

Husein, Umar. 2003. Riset Sumber Daya Manusia dalam organisasi. Cetakan ketiga. Jakarta : Gramedia Pustaka Utama.

Kurniati, Sundarsih. 2009. Budidaya Tanaman Kedelai. Jakarta : Gramedia

Sarwanto, A. 2008. Budidaya Kedelai Tropika. Jakarta : Penebar Swadaya

Sarwono. 2015. Analisis Jalur Untuk Riset Bisnis dengan SPSS. Yogyakarta : Penerbit Andi

Semuel, H., dan Saputra, R. 2013. Analisis Pengaruh Motivasi, Persepsi, Sikap Konsumen Terhadap Keputusan Pembelian Mobil Daihatsu Xenia di Sidoarjo. Jurnal Manajemen Pemasaran 1(1) : 1 - 12.

Trihedradi. 2012. Analisis Data Statistik. Yogjakarta : Penerbit Andi

Zulkarnain et al. 2010. Keunggulan Komparatif dan Kompetitif dalam Produksi Padi Di Kabupaten Lampung Tengah Propinsi Lampung. Jurnal Pertanian Terapan 10(3) : 185 - 199 